2. The heats of combustion of linseed mucilage and citrus pectin have been measured, the computed values for the hypothetically 'pure' materials being 4 ' ror and $3.719 \mathrm{Cal} . / \mathrm{g}$. respectively.

We wish to thank Mr A. M. Gallacher for valuable assistance, and the Rosella Fruit Preserving Co. and Dr G. H. Josephs, California Fruit Growers' Exchange, for supply of, and information concerning, the commercial citrus pectin.

\title{
REFERENCES
}

Benedict, F. G. \& Osborne, T. B. (1907). \%. biol. Chem. 3, 119.

Jessup, R. S. \& Green, C. B. (1934). F. Res. nat. Bur. Stand., Wash., 13, 469.

Lugg, J. W. H. (1939). Protein Metabolism in the Plant. By A. C. Chibnall, Appendix I. New Haven:

Yale University Press.

Lugg, J. W. H. \& Weller, R. A. (1944). Biochem. Y. 38, 408.

Lugg, J. W. H. \& Weller, R. A. (1948). Biochem. F. 42, 408.

Lunge, G. \& Berl, E. (1921). Chemisch-technische Untersuchungen, 7th ed., 1, 430. Berlin: Julius Springer.

\section{The Digestibility and Absorption of the Calories, Proteins, Purines, Fat and Calcium in Wholemeal Wheaten-Bread}

\author{
By R. A. McCANCE and C. M. WALSHAM \\ Department of Experimental Medicine, University of Cambridge
}

(Received II November 1947)

Wheat is so important in human affairs that its digestibility has been investigated on many occasions. The literature was summarized and fresh experiments carried out by Borgström (1941), Macrae, Hutchinson, Irwin, Bacon \& McDougall (1942), Heupke (1943), McCance, Widdowson, Moran, Pringle \& Macrae (1945), Brull, Barac, Brakier-Zelkowiecz, Clemens, Crismer, Deltombe, Divry, Dubois, Dumont, DumontRuyters, Lambrechts, Neuprez, Nizet, Op de Beeck, Piersotte \& Thomas (1945) and by McCance \& Widdowson (1947). There are, however, matters still in dispute and aspects which have not been investigated, and the work now to be described was undertaken in an attempt to clarify some of the points at issue. The following seemed to be outstanding problems.

(r) Calories. Moran \& Pace (1942) rightly pointed out that the digestibility of wheat flour, in terms of energy, did not depend so much upon its percentage extraction as upon the amount of bran which it contained, and they suggested a method for assessing the digestibility of high-extraction flours from their fibre content. They took some data which had recently been obtained by Macrae et al. (1942) for the digestibility of $73 \%$ and wholemeal flours. They showed that the difference could be accounted for by supposing that every increase in fibre of $0.2 \%$ (over a basal figure of about $0.15 \%$ ) led to a decrease in digestibility of about $I \cdot I \%$. The possibilities of this 
simple conception were obvious, but its value was limited by the paucity of data relating fibre values to digestibility. The present experiments afforded an opportunity of providing more information on this matter, and the question will be discussed in the light of the new data and figures which were obtained by McCance \& Widdowson (1947).

The shortage of wheat in the world and questions arising out of its supply to European countries have redirected attention to the assessment of its true calorific value and the factors to be used for converting its proximate principles into terms of energy. The Food and Agriculture Organization of the United Nations appointed a committee to study, and report on, the calculation of calorie values of foods, and the appointment was endorsed by a recommendation of the Food and Nutrition Board of the National Research Council of the United States. The American practice has been to multiply the protein, fat and carbohydrate (determined 'by difference') in all foods, including wheat, by 4,9 and 4 , respectively, and to assume that the result gives the available calories. These factors were recommended by Atwater for calculating the calorific value of mixed diets. They do not necessarily apply to single foods (McCance et al. 1945; Committee on Calorie Conversion Factors, 1947), and therefore their application to some diets may give an erroneous estimate of the available calories in them. The English practice has been to determine the available carbohydrate in foods, and McCance \& Widdowson ( $1946 a$ ) expressed this as glucose and used a factor 3.75 to convert the glucose to calories. This allowed nothing for digestibility. They used factors 9.3 and $4 \cdot I$ for fat and protein, which were originally worked out by Rubner on a dog (Sherman, 1937), and they have assumed that these factors allowed a negligible amount for digestibility, so that the calories given by them refer to the calories in the food and make no allowance for losses in faeces. It might have been more correct to have used the factors $9^{\circ} 4$ and 4.3 , but these differences are probably unimportant. These factors of McCance \& Widdowson may correctly be applied to any food or to a mixed diet, but they make no allowance for digestibility as Atwater's factors were intended to do. The calcium, phosphorus and other minerals in foodstuffs are always expressed in this way, although a percentage, sometimes a large percentage, is known not to be absorbed. The present experiments were planned so that the results might be used to compare the two methods of computing the calorific value of whole wheat, and to suggest the most correct factors to be used for assessing the available calories in it.

(2) Proteins. There is no dispute that raising the extraction rate increases the amount of $\mathrm{N}$ in the faeces. The question is to what extent this increase is due to undigested and, therefore, unabsorbed protein in the outer layers of the grain, and to what extent it is due to increased intestinal secretions provoked by the branny parts of the wheat. At one time the increase was generally attributed to the indigestibility of the protein, particularly in the aleurone layers, but latterly the opinion has been gaining ground that this protein is well digested, and that the increase of $\mathrm{N}$ in the faeces, brought about by raising the extraction rate, is due to the protein in the intestinal secretions. Thus Borgström (194I) showed that bran proteins were extensịvely digested in vitro, and reviewed the question of whether the proteolytic enzymes of the gut could penetrate the cells of the aleurone layer. He also carried out some metabolism experiments 
on man. His periods were only 3 days in length, and seem short by modern standards, but he found that bran, which had been predigested in vitro and, therefore, contained very little protein, raised the amount of $\mathrm{N}$ excreted in the faeces to almost the same extent as an equivalent weight of natural bran. Heupke (1943) found that duodenal juice acting in vitro digested up to $77 \%$ of the proteins in wheat bran, and he claimed that the amount of protein in bran was reduced from 14 to $2 \%$ by passage through the intestinal tract. He considered that the efficiency of the digestive process was due to the fact that the walls of the aleurone layer of cells were permeable to proteolytic enzymes. Booth \& Moran (1946) showed that pepsin, followed by trypsin, brought into solution in vitro about $65 \%$ of the $\mathrm{N}$ in bran and one would certainly expect digestion to be more complete in the intestinal tract. McCance \& Widdowson (1947) approached the matter in a different way. They carried out metabolism experiments with two wheatmeals of $90 \%$ extraction. The Manitoba meal contained $13.51 \%$ of protein on a $15 \%$ moisture basis, and the English $8.32 \%$. Each contained $1.15 \%$ of fibre. The amount of $\mathrm{N}$ found in the faeces was the same in each experiment and was, therefore, independent of the amount of $\mathrm{N}$ in the meals. The authors concluded that all the faecal $\mathrm{N}$ must have been derived from the intestinal juices and that the proteins in $90 \%$ wheatmeals were completely digested and absorbed. It was clear that further experiments with wholewheat meals were desirable and these have now been carried out.

(3) Purines. Von Fellenberg (1918) showed that whole wheaten meal contained between four and five times as much purine $\mathbf{N}$ as white flour, and that most of the purine derivatives were concentrated in the germ and in the aleurone layer of the grain. In their experimental study of rationing carried out in 1940, McCance \& Widdowson $(1946 b)$ drew attention to the fact that a diet consisting largely of vegetables and bread, made from a high-extraction flour, might provide surprisingly large amounts of purine $\mathrm{N}$, and McCance et al. (1945) discovered that high-protein Canadian wheats contained more purine $\mathrm{N}$ than low-protein English wheats. No references have been found to the absorption or metabolism of wheat purines, and it was decided, therefore, to take the present opportunity of investigating the matter.

(4) Fat. It is generally assumed that about $95 \%$ of the fat in a mixed diet is absorbed (Langworthy \& Holmes, 1917 $a, b$; Sherman, 1937; Sealock, Basinski \& Murlin, 1941; Basu \& Nath, 1946). Indeed, the factor 9 which is often used to convert the amount of fat found in a foodstuff into terms of available energy is based upon this assumption. A recent estimate (Committee on Calorie Conversion Factors, 1947) has given $90 \%$ as the digestibility of the fat in cereals of all extractions. McCance \& Widdowson $(1946 b)$, however, on the basis of metabolism experiments, suggested that the fat in long-extraction wheaten meals and in vegetables might be absorbed much less completely than this, and Basu (1946) and Basu \& Nath (1946) showed without comment that only some $55-65 \%$ of the fat in a diet consisting of rice, pulses, vegetables and fish was absorbed. Macrae et al. (1942) determined the ether-soluble material in the bread and faeces of their subjects, but their data cannot very well be used to determine the digestibility of the fat in wheat, because the subjects were eating $37 \mathrm{~g}$. of margarine a day. Apart from these experiments the digestibility of the fat in cereals has been little studied, and it is obviously important in considering the 
factors which should be used to calculate the true calorific value to the body of the fat in wheat or other cereals.

(5) Calcium. When Murlin, Marshall \& Kochakian (1941) wrote their paper on the digestibility of whole-wheat and white bread, they pointed out in favour of the former that 'the consumer would get...more minerals especially calcium...'. Since that time, however, the biological effects of the phytic acid in whole cereals have been carefully explored, and it is now generally recognized that whole wheat in a diet is likely to inhibit rather than promote the absorption of calcium. This has been borne out by the present experiments.

\section{EXPERIMENTAL}

The experiments were in part an extension of those made by McCance \& Widdowson (1947). Metabolism studies were carried out with two wholemeal flours. One was made from a high-protein Canadian wheat and the other from a low-protein English wheat. The principles underlying this method of approach were fully set out when the earlier experiments were made and will be alluded to again when the present results are discussed. The composition of the two meals (on a $15 \%$ moisture basis) is given in Table I.

Table 1. The compasition of the experimental wheaten meals on a $15 \%$ moisture basis

$\begin{array}{lcc} & \begin{array}{c}\text { Canadian wheat } \\ (\mathrm{g} . / 100 \mathrm{~g})\end{array} & \begin{array}{c}\text { English wheat } \\ (\mathrm{g} . / \mathrm{ro0} \mathrm{g} .)\end{array} \\ & 15.40 & 8.52 \\ \text { Protein }(\mathrm{N} \times 5.83) & 0.025 & 0.012 \\ \text { Purine } \mathrm{N} & 2.36 & 2.02 \\ \text { Fibre } & 2.23 & 1.83 \\ \text { Fat } & 55.20 & 63.60 \\ \begin{array}{l}\text { Available carbohydrate (sum of the } \\ \text { starch as starch, and the sugar as }\end{array} & & \\ \text { 8ugar) } & & \\ \text { Undetermined matter (pentosans, etc.) } & 9.78 & 9.02\end{array}$

\section{Subjects}

The experiments were carried out on three men and three women. They were divided into two groups and their initials, occupation, sex, age, height and weight were as follows. Group I: E. G., physician, $\delta, 33,180 \mathrm{~cm}$., $86 \mathrm{~kg}$.; A. H., research student, $q$, $21,161 \mathrm{~cm}$., $46 \mathrm{~kg}$.; R. M., physician, $\delta, 48,180 \mathrm{~cm}$., $57 \mathrm{~kg}$. Group 2: D. H., radiographer, \&, 25, $176 \mathrm{~cm}$., $66 \mathrm{~kg}$; P. J., physician, $\delta, 35,176 \mathrm{~cm}$., $66 \mathrm{~kg}$.; C. W., research student, $q, 22,159 \mathrm{~cm}$., $52 \mathrm{~kg}$.

\section{Experimental arrangement}

The experiment was divided into two parts. Each lasted for I I days and consisted of: (a) 3 preliminary days when the experimental food was taken but no excreta collected; (b) 7 days during which all the urine passed was collected; carmine was taken before the first meal and faeces were saved from the time it appeared; $(c)$ an after-time, varying from 12 to $30 \mathrm{hr}$., in which carmine was taken before the first meal, and the experimental diet was continued until it appeared. Between the two experimental periods 
there was an interval of 3 days during which the subjects took their normal diet. To minimize the effects of external conditions, practice or staleness on the part of the subjects, and other things, the first group ate bread made from Canadian wheat in the first period and changed to bread made from English wheat in the second, whereas the second group began with bread made from English wheat and passed on to bread made from Canadian wheat. Each person was given in the first period as much bread as he or she desired, and an equal amount, on a dry-matter basis, in the second.

\section{Diet}

This consisted largely of bread, which was baked for us by Mr and Mrs Wilkin, of Barrington, Cambridgeshire. For each kg. of flour $25 \mathrm{~g}$. fresh yeast and $25 \mathrm{~g}$. salt were used. The Canadian flour was baked into rectangular loaves, the English flour into flat cakes, partly to reduce a tendency of the latter to crumble and partly to make it easy to distinguish the two kinds of bread. The only other constituents of the diet were small amounts of golden syrup, bramble and marmalade jelly. The drinks permitted were water and weak tea without milk. Thus the flour constituted the sole source of $\mathbf{N}$, fat and fibre, and, as shown in Table 2 , it provided $85 \cdot 8-100 \%$ of the total calories.

\section{Excreta}

The faeces were collected in tared glass bowls and sprayed daily with $0.1 \mathrm{~N}-\mathrm{HCl}$. The women took the precautions described by McCance \& Widdowson (1947) to prevent contamination of the faeces with urine. The faeces were prepared for sampling as described by McCance \& Widdowson (1942). Duplicate portions of $20 \mathrm{~g}$. were then treated with $20 \mathrm{ml}$. of conc. $\mathrm{H}_{2} \mathrm{SO}_{4}$, allowed to stand for 3 or 4 days, diluted accurately to $100 \mathrm{ml}$. and stored in bottles. These emulsions were used for the determination of total N. Duplicate $50 \mathrm{~g}$. portions of the mixed faeces were placed in crucibles, dried and ashed, and the calcium determined (McCance \& Widdowson, 1942). For fibre and calorie determinations two samples of 100 or $150 \mathrm{~g}$. of mixed faeces were dried at $95^{\circ}$ to constant weight, ground up quickly and stored in tightly stoppered tubes in a desiccator. One-tenth of the volume of urine passed during the 7 days was saved and stored under toluene. Care had to be taken to prevent the loss of uric acid crystals which tended to separate on cooling. Sometimes the urines had to be diluted and carefully warmed to get the uric acid back into solution. The total $\mathrm{N}$ and uric acid were determined, and, for the estimation of calcium, duplicate $100 \mathrm{ml}$. samples were acidified with conc. $\mathrm{HNO}_{3}$, dried, incinerated and the ash extracted with $\mathrm{HCl}$ (McCance \& Widdowson, 1942).

\section{Analytical techniques}

The total $\mathbf{N}$ in the bread, flour and faeces was determined by the Kjeldahl method (McCance \& Shipp, 1933) using copper selenide as catalyst and heating for many hours after the digests had first cleared. Purine $\mathrm{N}$ was determined by the method of von Fellenberg (1918) (McCance \& Shipp, 1933) and also by the method of Graff \& Maculla (1935). For moisture a weighed portion was heated at $100-105^{\circ}$ till there was 
no further loss of weight. The calorific values of the breads, flours and faeces were determined by bomb calorimeter. The calorific value of the syrup and jellies was arrived at by calculation, using the figures and factors given by McCance $\&$ Widdowson ( $1946 a)$. Fat in the meals and bread was determined by one of the American 'official' methods (Association of Official Agricultural Chemists, 1945, p. 240), and in the faeces by the same method and also by that of von Lieberman \& Szekely (1898). For the fibre a modification of the method described in the Fertilisers and Feeding Stuffs Regulations (Great Britain Parliament, I932) was used. The final filtration was carried

Table 2. The digestibility of calories in diets consisting largely of wholemeal breads made from Canadian and English wheat

\begin{tabular}{|c|c|c|c|c|c|c|}
\hline \multicolumn{7}{|c|}{ (Values for a period of 7 days) } \\
\hline & \multirow[b]{2}{*}{$\begin{array}{c}\text { Intake } \\
\text { of bread, } \\
\text { dry weight } \\
\text { (g.) }\end{array}$} & \multicolumn{3}{|c|}{ Source of calories } & \multirow[b]{2}{*}{$\begin{array}{l}\text { Calories } \\
\text { in faeces }\end{array}$} & \multirow[b]{2}{*}{$\begin{array}{c}\text { Digestibility } \\
\text { of total } \\
\text { calorie intake } \\
(\%)\end{array}$} \\
\hline Subject & & $\begin{array}{l}\text { Calories } \\
\text { in food }\end{array}$ & $\begin{array}{c}\text { From } \\
\text { wheat } \\
(\%)\end{array}$ & $\begin{array}{c}\text { From } \\
\text { sugars } \\
(\%)\end{array}$ & & \\
\hline \multicolumn{7}{|c|}{ Canadian wheat } \\
\hline $\begin{array}{l}\text { E.G. } \\
\text { A.H. } \\
\text { D.H. } \\
\text { P.J. } \\
\text { R.M. } \\
\text { C.W. }\end{array}$ & $\begin{array}{l}6,340 \\
3,390 \\
4,030 \\
4,150 \\
5,485 \\
3,345\end{array}$ & $\begin{array}{l}28,498 \\
16,068 \\
18,934 \\
21,022 \\
24,000 \\
15,555\end{array}$ & $\begin{array}{c}97 \cdot 4 \\
92 \cdot 4 \\
93 \cdot 1 \\
86 \cdot 4 \\
100 \\
94 \cdot 2\end{array}$ & $\begin{array}{l}2 \cdot 6 \\
7 \cdot 6 \\
6 \cdot 9 \\
13 \cdot 6 \\
0 \\
5 \cdot 8\end{array}$ & $\begin{array}{l}3,940 \\
1,770 \\
2,280 \\
2,150 \\
3,040 \\
1,820\end{array}$ & $\begin{array}{l}86 \cdot 2 \\
89 \cdot 0 \\
88 \cdot 0 \\
89 \cdot 8 \\
87 \cdot 3 \\
88 \cdot 3\end{array}$ \\
\hline Average & 4,457 & 20,680 & $93 \cdot 9$ & $6 \cdot 1$ & 2,500 & $88 \cdot 0$ \\
\hline \multicolumn{7}{|c|}{ English wheat } \\
\hline $\begin{array}{l}\text { E.G. } \\
\text { A.H. } \\
\text { D.H. } \\
\text { P.J. } \\
\text { R.M. } \\
\text { C.W. }\end{array}$ & $\begin{array}{l}6,340 \\
3,390 \\
4,030 \\
4,150 \\
5,485 \\
3,345\end{array}$ & $\begin{array}{l}26,848 \\
15,188 \\
17,904 \\
19,942 \\
22,580 \\
14,685\end{array}$ & $\begin{array}{c}97 \cdot 1 \\
92 \cdot 0 \\
92 \cdot 7 \\
85 \cdot 8 \\
100 \\
93 \cdot 9\end{array}$ & $\begin{array}{l}2 \cdot 0 \\
8 \cdot 0 \\
7 \cdot 3 \\
14 \cdot 2 \\
0 \\
6 \cdot 1\end{array}$ & $\begin{array}{l}3,380 \\
1,570 \\
I, 880 \\
1,920 \\
2,695 \\
1,545\end{array}$ & $\begin{array}{l}87 \cdot 4 \\
89 \cdot 7 \\
89 \cdot 5 \\
90 \cdot 4 \\
88 \cdot 1 \\
89 \cdot 5\end{array}$ \\
\hline Average & 4,457 & 19,525 & $93 \cdot 6$ & $6 \cdot 4$ & 2,165 & $89 \cdot 0$ \\
\hline
\end{tabular}

out by suction through weighed papers (diam. $5.5 \mathrm{~cm}$.), and thus the transference of the fibre from one paper to another was avoided. The papers were treated with boiling alkali and subsequently washed in accordance with the details given in the method before they were dried and weighed. The uric acid in the urines was determined colorimetrically using Benedict reagent as described by Cole (1933). The calcium methods have been given by McCance \& Widdowson (r942) and McCance \& Shipp (1933). The available carbohydrate was determined as starch + sugar, using American 'official' methods advocated for these substances (Association of Official Agricultural Chemists, I945, pp. 249, 409).

\section{Digestibility of calories}

RESULTS AND DISCUSSION

Table 2 gives the calorie intakes and outputs. The former were slightly lower when the subjects were eating the English wheat because it had a slightly lower energy value/g., but the difference was probably too small to matter. Each subject absorbed 
rather more of the energy value of the English than of the Canadian wheat, and the averages were 89 and $88 \%$, respectively. Though small, this difference was statistically significant $(t=6.95, P=0.01)$, and probably resulted from the fact that the Canadian wheat contained more fibre than the English wheat. Table 3 shows the digestibility of

Table 3. The digestibility of fibre in diets consisting largely of wholemeal breads made from Canadian and English wheat

(Values for a period of 7 days)

\begin{tabular}{|c|c|c|c|c|c|c|}
\hline \multirow[b]{2}{*}{ Subject } & \multicolumn{3}{|c|}{ Canadian wheat } & \multicolumn{3}{|c|}{ English wheat } \\
\hline & $\begin{array}{c}\text { Fibre } \\
\text { in food } \\
(\mathrm{g} .)\end{array}$ & $\begin{array}{c}\text { Fibre } \\
\text { in faeces } \\
(\mathrm{g} .)\end{array}$ & $\begin{array}{c}\text { Digestibility } \\
(\%)\end{array}$ & $\begin{array}{l}\text { Fibre } \\
\text { in food } \\
\text { (g.) }\end{array}$ & $\begin{array}{c}\text { Fibre } \\
\text { in faeces } \\
\text { (g.) }\end{array}$ & $\begin{array}{c}\text { Digestibility } \\
(\%)\end{array}$ \\
\hline $\begin{array}{l}\text { E.G. } \\
\text { A.H. } \\
\text { D.H. } \\
\text { P.J. } \\
\text { R.M. } \\
\text { C.W. }\end{array}$ & $\begin{array}{r}176 \cdot 0 \\
94.3 \\
112.0 \\
115.3 \\
152.4 \\
93.0\end{array}$ & $\begin{array}{r}139.0 \\
72.0 \\
88.9 \\
82.9 \\
112.5 \\
73.4\end{array}$ & $\begin{array}{l}21 \cdot 0 \\
23 \cdot 6 \\
20 \cdot 6 \\
28 \cdot 2 \\
26 \cdot 1 \\
21 \cdot 1\end{array}$ & $\begin{array}{r}151 \cdot 0 \\
80 \cdot 7 \\
96 \cdot 0 \\
98 \cdot 8 \\
130 \cdot 5 \\
79 \cdot 6\end{array}$ & $\begin{array}{r}125 \cdot 5 \\
62 \cdot 5 \\
76 \cdot 0 \\
73 \cdot 5 \\
104.4 \\
60.8\end{array}$ & $\begin{array}{l}16.9 \\
22.5 \\
20.9 \\
25.6 \\
20.0 \\
23.6\end{array}$ \\
\hline Average & $123 \cdot 8$ & $94 \cdot 8$ & $23 \cdot 4$ & $106 \cdot 1$ & $83 \cdot 8$ & $21 \cdot 6$ \\
\hline
\end{tabular}

the fibre in the two wheats. The larger intakes will be noted when the subjects were eating the Canadian wheat. The average figures suggest that the fibre in this wheat may have been slightly better digested than the fibre in the English wheat. Nevertheless, considerably more fibre was excreted when the Canadian wheat was being eaten. The larger amounts of fibre in the faeces of the subjects when they were eating Canadian meal will not of course account for the additional calories in the faeces on this diet (Table 2), but it is well known that increasing the amount of chemically determined fibre in the diet greatly increases the bulk and calorific value of the faeces.

A prediction based on the work of Moran \& Pace (1942) would have given these wheatmeals digestibilities of $85.8 \%$ for the English wheat and $84.1 \%$ for the Canadian wheat. These are much too low, and similar predictions were also too low for the digestibilities found by McCance \& Widdowson (1947) for wheatmeals containing $1 \cdot 15 \%$ of fibre. The data have been summarized in Fig. I. It looks as though the digestibilities given by Macrae $e t$ al. (1942) for their $100 \%$ wheatmeals were not

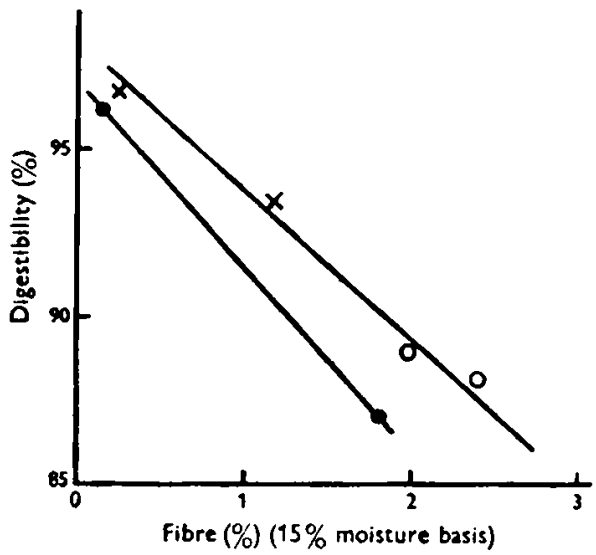

Fig. I. The effect of fibre content on the digestibility of wheat. data of Macrae et al. (1942), $\times$ data of McCance \& Widdowson (1947), $O$ data obtained in the present investigation.

high enough for Moran \& Pace to have generalized from them. The low digestibility values found in the experiments of Macrae et al. (1942) may be explained in several ways. In the first place they assumed that the constituents of their diets other than bread 
were completely digested, and the figures given by them for the digestibility of wheat were based upon the assumption that the whole of the calorific value of the faeces was due to the wheat which had been consumed. This statement also applies to the digestibilities given by McCance $\&$ Widdowson (1947), and to those given by the present experiments, but in the work of Macrae et al. the bread only accounted for $75 \%$ of the total calorie intake whereas in McCance \& Widdowson's studies it accounted for nearly $82 \%$. In the present experiments, as Table 2 shows, the bread accounted for over $90 \%$ of the calorie intake, and with one subject for $100 \%$ of the intake. It is known that the constituents of the diet other than wheat must make some contribution to the calorific value of the faeces, and this applies particularly to the fat, so that when Macrae et al. assumed that the calorific value of the faeces was due only to the bread they had eaten, they were making no more assumptions than the later workers, but these assumptions may have led them farther from the truth.

A second reason for the lower digestibilities found by Macrae $e t$ al. may have been that the wheats were not the same or, indeed, that the subjects were not the same, as those used in the present experiments. One or other of these differences caused the fibre in the wholemeal breads of Macrae et al. to be less well digested than the fibre in the breads used in the later experiments, and may well have led to the differences in calorie digestibility now under discussion, but it is impossible to make any further analysis of the cause. Moran \& Pace (r942) further suggested that an increase of $0.2 \%$ in the amount of fibre in a wheatmeal decreased its digestibility by about $I \cdot x \%$. It appears from the data given in Fig. I that this prediction may be justified, for the slope of the line given by more recent experiments is very much the same as that given by those of Macrae et al. (1942).

\section{The nitrogen balances and the digestibility of protein}

Table 4 gives the $\mathrm{N}$ balance data when wheat formed $86-100 \%$ of the calorific value of the diets and accounted for the whole of the protein intake. It will be seen that the Canadian wheat provided nearly twice as much protein as the English wheat. It will probably be a surprise to many people that wheat, which is so often thought of solely as a source of carbohydrate, should have provided one subject with $161 \mathrm{~g}$. protein $(\mathrm{N} \times 5.83)$ per day. The average for the six subjects when they were eating the Canadian wheat was I $13 \mathrm{~g}$./day. Five of the six subjects were in positive $\mathrm{N}$ balance on these high intakes and five were in negative $\mathrm{N}$ balance when they were eating the English wheat. This should probably not be taken to mean that the subjects were not getting a sufficient amount of all the necessary amino-acids from the proteins in the English wheat to satisfy their requirements, but that they had not been allowed time to come into $\mathrm{N}$ equilibrium on either kind of wheat before beginning the experiment.

Although the $\mathbf{N}$ intakes were so much greater when the subjects were eating the Canadian wheat, the amount of $\mathrm{N}$ in the faeces was little greater on one diet than on the other. True, with two of the subjects it was appreciably higher on the Canadian wheat, but with the other four it was almost the same. In the experiments of McCance \& Widdowson (1947) with $90 \%$ wheatmeals the fibre contents of the two meals were 
equal, and so were the values for the digestibility of calories. On both diets the amounts of $\mathrm{N}$ in the faeces were also equal, and this was assumed to be due to the fact that the protein in each wheatmeal was completely digested and absorbed, that the $\mathrm{N}$ found in the faeces was all metabolic $\mathrm{N}$, and that its amount did not depend upon the amount of protein in the meal, but that it did depend upon other characteristics, particularly the content of fibre. Now, in the present experiments, four of the subjects

Table 4. Nitrogen balances and digestibility of nitrogen in diets consisting largely of wholemeal breads made from Canadian and English wheat

(Values for a period of 7 days)

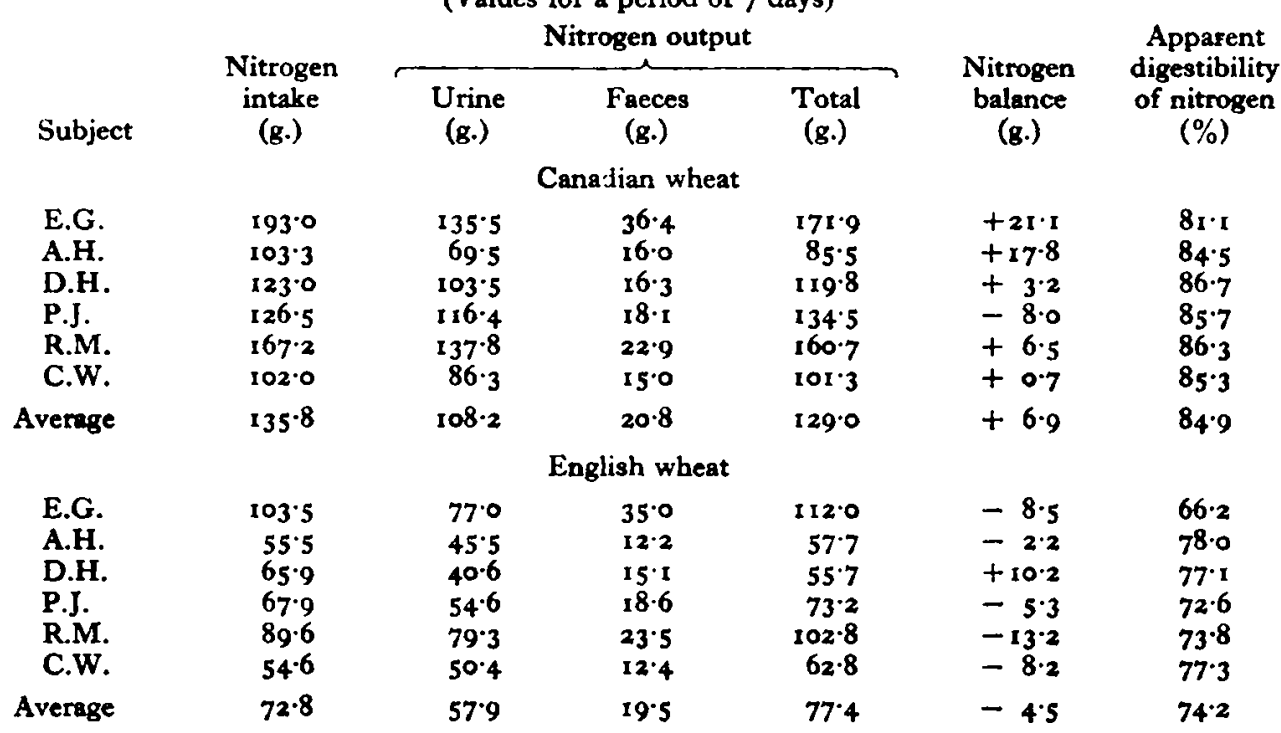

appear to have given results on $100 \%$ meals similar to the earlier results obtained with $90 \%$ meals. They digested and absorbed all the wheat protein, whereas the two remaining subjects digested the protein rather less completely. The wheatmeals used for the present experiments, hovgever, did not contain the same amounts of fibre, nor were their calories equally digestible. It is well known that an increase in fibre in a meal is associated with a decrease in the digestibility of the calories, and also in the apparent digestibility of protein, so that the figures given in Table 4 require to be corrected for this effect before they can be used to compute the true digestibility of the wheat protein in the two meals. In the experiments carried out by McCance \& Widdowson (1947) a change from 80 to $90 \%$ English wheatmeal involved the addition (on the average) of $47 \mathrm{~g}$. of fibre to the diet over a period of 7 days and caused an increased excretion of $2.4 \mathrm{~g}$. of $\mathrm{N}$. This was undoubtedly too small an increase in the excretion of $\mathrm{N}$ because the $80 \%$ English meal caused digestive upsets and some diarrhoea. A more correct estimate of the effect of fibre on the excretion of $\mathrm{N}$ may be obtained from the experiments with the Manitoba wheat. In them the addition of $3^{8} \mathrm{~g}$. of fibre to the week's food led to the excretion of a further $3.5 \mathrm{~g}$. N. These figures for Manitoba wheat have been used to 'correct' the present data, and it is to be noted that the correction involves no assumptions as to why an increase of fibre in the food leads to an 
increased excretion of $\mathrm{N}$. The steps in the correction are shown in Table 5 , and it will be seen that after they had been taken the average excretion of $\mathbf{N}$ was slightly lower when the subjects were eating the Canadian wheat although it contained nearly twice as much protein as the English. It may be concluded that even in wholemeal flours the protein is completely, or almost completely, digested and absorbed in its passage along the human alimentary tract. The true digestibility of wheat protein, in other words, is

\section{Table 5. The excretion of faecal $N$ on diets made up of English and Canadian wholemeal breads and its 'correction' to an equal fibre basis}

(Values for a period of 7 days)

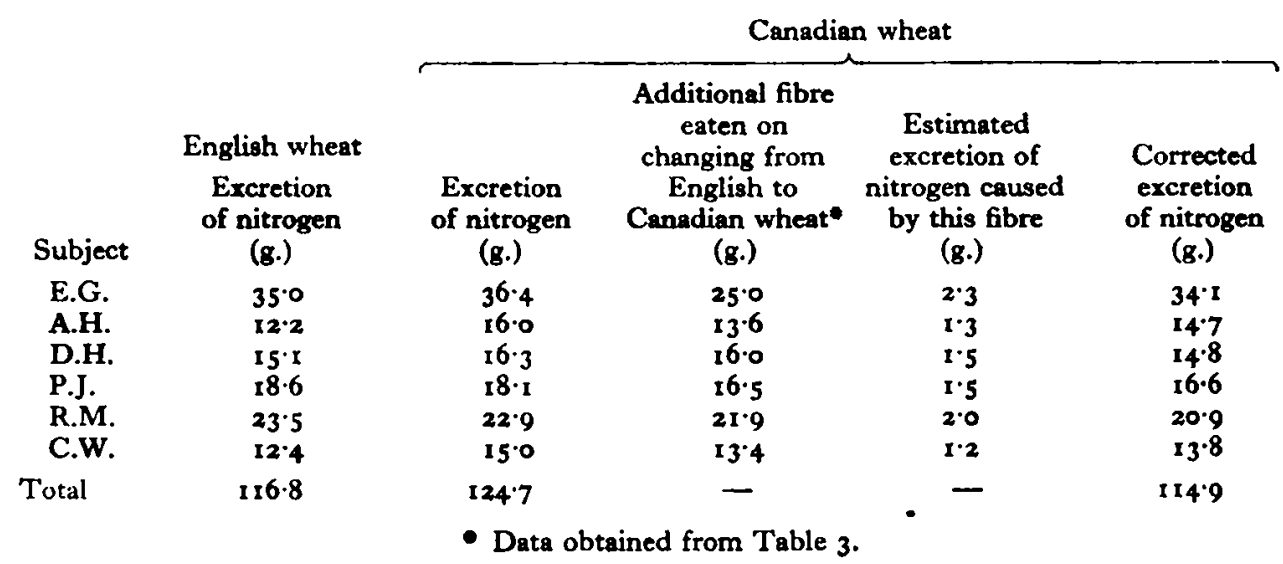

$100 \%$ or very near it. This is a much higher figure than has hitherto been supposed, or than the figure obtained, for example, by Henry \& Kon (1945) when they were using Mitchell's method (Mitchell, 1924; Mitchell \& Carman, 1926) in experiments with rats. It is suggested that these methods be scrutinized and, if found to be faulty, abandoned. The effect of varying the percentage of protein in the wheat upon the apparent digestibility of that protein is clearly shown in the last column of Table 4 . It is evident that the apparent digestibility, which has been fully discussed by McCance \& Widdowson (1947), has little theoretical meaning.

\section{The digestibility of purines}

The quantities of purine $\mathrm{N}$ in the two flours are given in Table 1 . Both figures seem low in comparison with those obtained by McCance et al. (1945). The present figures have, however, been obtained by two people working independently, and one of them used two different methods. Like the previous figures, they show that the Canadian wheat contained much more purine $N$ than the English wheat. The ratios of purine $\mathrm{N} /$ total $\mathrm{N}$ in the two wheats were, indeed, about the same. Table 6 shows the intakes of purine $\mathbf{N}$ and the outputs of uric acid $\mathbf{N}$ during the two experimental periods. Each person excreted more uric acid $\mathbf{N}$ when eating Canadian wheat, and this must be attributed to the fact that the Canadian wheat contained so much more purine $\mathrm{N}$. The average intake of purine $\mathrm{N}$ from Canadian wheat exceeded the average intake from 
English wheat by $682 \mathrm{mg}$, and the average output of uric acid $\mathrm{N}$ when the subjects were eating Canadian wheat exceeded the output when they were eating English wheat by $367 \mathrm{mg}$. These figures would indicate that $55 \%$ of the wheat purines was being absorbed. There were, however, considerable individual variations, and on both diets all the subjects excreted more $\mathrm{N}$ as uric acid than they took in as purines. It is, therefore, unfortunate that no figures were obtained for the uric acid $\mathrm{N}$ excretions of these men and women on purine-free diets. If the amount is assumed to have been $120 \mathrm{mg}$./ day (corresponding to $360 \mathrm{mg}$./day of uric acid) (Best \& Taylor, 1945), the endogenous

Table 6. Intake and output of purines on diets consisting largely of wholemeal breads made from Canadian and English wheat

(Values for a period of 7 days)

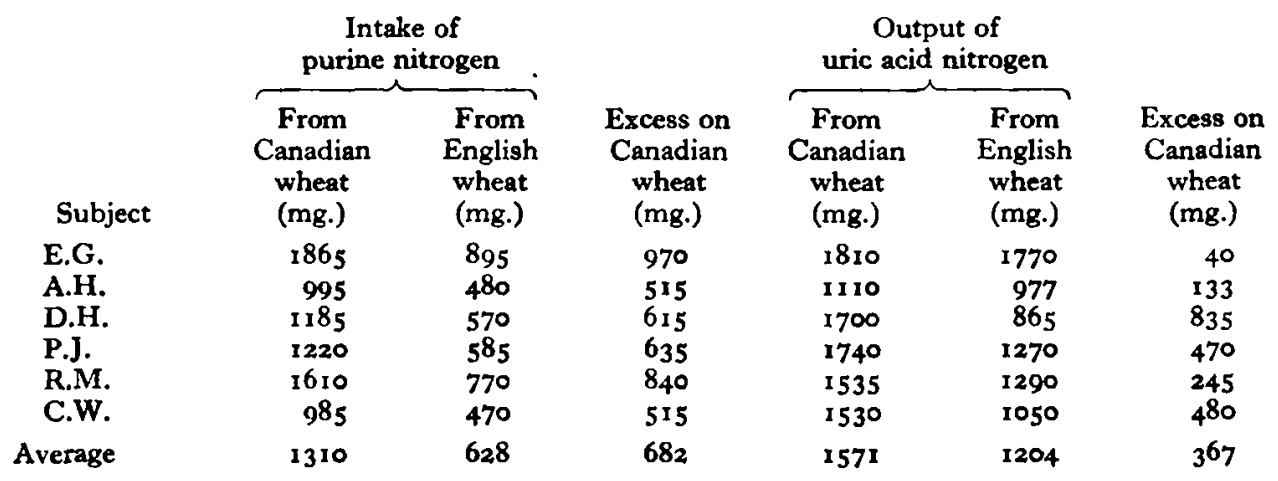

outputs of uric acid $\mathrm{N}$ would have been of the order of $840 \mathrm{mg}$./person/week, and it follows from this and from the data in Table 6 that $(1571-840) \times 100 / 1310=56 \%$ of the purine $\mathrm{N}$ in the Canadian wheat was absorbed and excreted in the urine and $(\mathrm{r} 204-840) \times 100 / 628=58 \%$ of the purine $\mathrm{N}$ in the English wheat. These figures agree well with the one of $55 \%$ already given, and it may be taken as a first approximation that $55-60 \%$ of the purine $\mathrm{N}$ in wheat is absorbed and excreted as uric acid. These results, moreover, in so far as they show that the Canadian wheat provided more uric acid $\mathrm{N}$ for excretion than did the English wheat, are an interesting biological confirmation of the chemical findings that the Canadian wheat contained more purine $\mathrm{N}$ than the English wheat.

Fat

Table 7 records the results for fat. It will be seen that the bread made from the Canadian wheat contained $2.62 \%$ of fat while that made from the English wheat contained $2 \cdot 15 \%$. These figures, which include traces of unsaponifiable matter, are not far from those found by McCance et al. (1945) in mixed samples of Manitoba and English wheat. The digestibility of the fat in the Canadian wheat varied from 53.6 to $74.9 \%$ and averaged $62.2 \%$. The digestibility of the fat in the English wheat varied from 48.5 to $59.4 \%$ and averaged $53.9 \%$. These figures are surprisingly low for the digestibility of a dietary fat, but the use of a titration method for faecal fat showed that they were not low on account of unsaponifiable matter in the stools, and they are in keeping 
with some of the work which has previously been discussed. It is evident, however, that unless the digestive secretions contain fat-which seems most unlikely-wheat fat must be digested much less efficiently than wheat protein. The difference may be due to the difficulty with which the lipolytic enzymes penetrate into the vegetable cells and with which the products of digestion escape. The work of Heupke (1943) certainly suggests this, for he found that the digestion of the proteins inside the cells of the aleurone layer allowed the particles of fat which had previously been finely dispersed in the cells to collect into larger droplets.

Table 7. The digestibility of fat in diets consisting largely of wholemeal breads made from Canadian and English wheat

\begin{tabular}{|c|c|c|c|}
\hline \multicolumn{4}{|c|}{ (Values for a period of 7 days) } \\
\hline Subject & $\begin{array}{c}\text { Fat in food } \\
\text { (g.) }\end{array}$ & $\begin{array}{c}\text { Fat in faeces } \\
\text { (g.) }\end{array}$ & $\begin{array}{l}\text { Digestibility of fat } \\
(\%)\end{array}$ \\
\hline \multicolumn{4}{|c|}{ Canadian wheat } \\
\hline $\begin{array}{l}\text { E.G. } \\
\text { A.H. } \\
\text { D.H. } \\
\text { P.J. } \\
\text { R.M. } \\
\text { C.W. }\end{array}$ & $\begin{array}{r}166.0 \\
88.8 \\
105.5 \\
108.8 \\
143.8 \\
87.7\end{array}$ & $\begin{array}{l}41 \cdot 6 \\
36.6 \\
46.4 \\
50.5 \\
53 \cdot 7 \\
28.9\end{array}$ & $\begin{array}{l}74 \cdot 9 \\
58 \cdot 8 \\
56 \cdot 1 \\
53 \cdot 6 \\
62 \cdot 6 \\
67 \cdot 0\end{array}$ \\
\hline Average & $116 \cdot 8$ & $49 \cdot 5$ & $62 \cdot 2$ \\
\hline \multicolumn{4}{|c|}{ English wheat } \\
\hline $\begin{array}{l}\text { E.G. } \\
\text { A.H. } \\
\text { D.H. } \\
\text { P.J. } \\
\text { R.M. } \\
\text { C.W. }\end{array}$ & $\begin{array}{r}136.0 \\
72.9 \\
86.6 \\
89.2 \\
118.0 \\
72.0\end{array}$ & $\begin{array}{l}55 \cdot 6 \\
35 \cdot 6 \\
43 \cdot 5 \\
36 \cdot 2 \\
60 \cdot 8 \\
32 \cdot 0\end{array}$ & $\begin{array}{l}59 \cdot 1 \\
5 x \cdot 2 \\
49 \cdot 7 \\
59 \cdot 4 \\
48.5 \\
55 \cdot 6\end{array}$ \\
\hline Average & $95^{\cdot 8}$ & $44^{\circ} \circ$ & $53 \cdot 9$ \\
\hline
\end{tabular}

The present results have some practical applications. If the chemical combustion of I g. of fat sets free 9.45 Cal., a digestibility of $95 \%$ (Atwater, see Sherman, 1937) demands the use of the factor 9 to convert the fat into terms of available calories. A digestibility of $90 \%$ (Committee on Calorie Conversion Factors, 1947) demands a factor of 8.5 . Since, however, wheat fat appears to have a digestibility of about $58 \%$, the factor to be used should be 5.5. Apart from its practical bearing the present study has drawn attention to an interesting but perhaps rather more academic question. Both the germ and the aleurone layer contain a high percentage of fat. Is the fat in the one better or less well digested than the fat in the other? This problem can easily be solved by further experiments.

\section{Calcium}

The calcium balances of three of the subjects were measured when they were eating the Canadian wheat, and of the other three when they were eating the English wheat. The results are shown in Table 8 . The tap water, used for drinking purposes and for 
making tea, contained some calcium, and it was not measured, but its volume was computed fairly accurately in the following way. The weather was very cold while these experiments were being made, and even the buildings were inadequately heated, so that the losses of water by the skin were undoubtedly minimal. An allowance of $800 \mathrm{ml}$./day was made for losses through the lungs and skin, and the intake of water of each subject was then calculated from his or her urine volume after allowing for the water set free by the metabolism of the protein, fat and carbohydrate in the diet. Most of this water was taken as very weak tea, so that the greater part of the calcium in it may have been precipitated in the kettle or teapot and may not have been ingested,

Table 8. Calcium balances on diets consisting largely of wholemeal breads made from Canadian and English wheat

\begin{tabular}{|c|c|c|c|c|c|c|c|}
\hline \multirow[b]{2}{*}{ Subject } & \multicolumn{3}{|c|}{ Calcium intake (mg./day) } & \multicolumn{3}{|c|}{ Calcium output (mg./day) } & \multirow{2}{*}{$\begin{array}{c}\text { Calcium } \\
\text { balance } \\
\text { (mg./day) }\end{array}$} \\
\hline & Bread & Water & Total & Faeces & Urine & Total & \\
\hline \multicolumn{8}{|c|}{ Canadian wheat } \\
\hline $\begin{array}{l}\text { E.G. } \\
\text { A.H. } \\
\text { R.M. }\end{array}$ & $\begin{array}{l}445 \\
246 \\
399\end{array}$ & $\begin{array}{r}108 \\
111 \\
89\end{array}$ & $\begin{array}{l}553 \\
357 \\
488\end{array}$ & $\begin{array}{l}663 \\
390 \\
537\end{array}$ & $\begin{array}{l}149 \\
109 \\
221\end{array}$ & $\begin{array}{l}812 \\
499 \\
758\end{array}$ & $\begin{array}{l}-259 \\
-142 \\
-270\end{array}$ \\
\hline \multicolumn{8}{|c|}{ English wheat } \\
\hline $\begin{array}{l}\text { D.H. } \\
\text { P.J. } \\
\text { C.W. }\end{array}$ & $\begin{array}{l}270 \\
277 \\
224\end{array}$ & $\begin{array}{l}75 \\
45 \\
94\end{array}$ & $\begin{array}{l}345 \\
322 \\
318\end{array}$ & $\begin{array}{l}414 \\
377 \\
269\end{array}$ & $\begin{array}{l}190 \\
132 \\
164\end{array}$ & $\begin{array}{l}604 \\
509 \\
433\end{array}$ & $\begin{array}{l}-259 \\
-187 \\
-115\end{array}$ \\
\hline
\end{tabular}

but the generous estimate has been made in constructing Table 8 that all the calcium in the tap water was actually ingested. It will be seen that all the calcium balances were negative, and, moreover, that of the six subjects five excreted more calcium in their stools than they took in by mouth. This was due to the fixation of the calcium of the digestive juices in the intestine by the phytic acid in the bread.

R.M. had an interesting experience at the close of these experiments. On the evening of the day on which his second ro-day period came to an end he began to have constant cramps in his fingers and toes. They reminded him of the cramps of salt deficiency, and were clinically indistinguishable. Towards the end of his evening meal, which was a large one, he found it quite difficult to control his spoon and fork, and after supper the cramps got much worse. This may have been due to the secretion of much hydrochloric acid in his gastric juice making his body fluids slightly more alkaline. Very stupidly, R.M. did not at once realize that he was suffering from a deficiency of calcium in his body fluids, but he tumbled to it next morning when he found out while shaving that he had a strongly positive Chvostek sign all over both sides of his face. As it was Sunday he decided to treat himself clinically rather than scientifically, and he took, therefore, as much milk as the household milkman could afford to let him have, and did not bother about his serum calcium. This was estimated on the following day when his cramps had almost gone but when he still reacted positively to Chvostek's test, and it was found to be $8.9 \mathrm{mg} . / 100 \mathrm{ml}$. 
The assessment of calories in wheat

McCance et al. (1945) discussed at some length the assessment of the total and available calories in wheat. The question has also been carefully considered by the committee set up by the Food and Agriculture Organization of the United Nations. The present work has provided a good opportunity of checking and expanding these discussions. For this purpose the percentage composition of the breads on a $15 \%$ moisture basis has been taken to be as follows (the figures for bread made from Canadian wheat being given first): protein 15.40 and 8.52 ; fat 2.23 and 1.83 ; available

Table 9. The assessment of calories in voheat

\begin{tabular}{|c|c|c|c|c|c|c|c|c|}
\hline \multirow[b]{5}{*}{ Type of wheat } & \multicolumn{2}{|c|}{$\begin{array}{l}\text { Total energy } \\
\text { (Cal./100 g.) }\end{array}$} & \multirow{2}{*}{\multicolumn{6}{|c|}{ Available energy ( $\mathrm{Cal} / \mathrm{/} 100 \mathrm{~g}$.) }} \\
\hline & \multirow{4}{*}{$\begin{array}{l}\text { Determined } \\
\text { by bomb } \\
\text { calorimeter }\end{array}$} & \multirow{4}{*}{$\begin{array}{l}\text { Calculated } \\
\text { by the use } \\
\text { of factors } \\
5.65,9 \cdot 45 \\
\text { and } 4 \cdot 2 \text { for } \\
\text { protein, fat } \\
\text { and available } \\
\text { carbohydrate, } \\
\text { respectively }\end{array}$} & & & & & & \\
\hline & & & Bomb calor & imeter values & \multirow{2}{*}{\multicolumn{4}{|c|}{ Calculated values }} \\
\hline & & & \multirow{2}{*}{$\begin{array}{c}\text { Corrected } \\
\text { for } \\
\text { digestibility }\end{array}$} & \multirow{2}{*}{$\begin{array}{l}\text { Corrected for } \\
\text { digestibility } \\
\text { and incomplete } \\
\text { combustion }\end{array}$} & & & & \\
\hline & & & & & I* & $2 *$ & $3 *$ & $4^{\circ}$ \\
\hline $\begin{array}{l}\text { Canadian } \\
\text { English }\end{array}$ & $\begin{array}{l}372 \\
350\end{array}$ & $\begin{array}{l}339 \\
332\end{array}$ & $\begin{array}{l}327 \\
310\end{array}$ & $\begin{array}{l}310 \\
302\end{array}$ & $\begin{array}{l}344 \\
343\end{array}$ & $\begin{array}{l}299 \\
304\end{array}$ & 324 & $\begin{array}{l}320 \\
320\end{array}$ \\
\hline
\end{tabular}

I* Factors 4, 9 and 4 for protein, fat and carbohydrate, respectively, the last having been determined by difference and including fibre.

2* Factors (Canadian wheat) $3.65,5.5$ and 4.2 for protein, fat and available carbohydrate, respectively. Factors (English wheat) $3.21,5.5$ and 4.2 for protein, fat and availsble carbohydrate, respectively.

$3^{\circ}$ Factors $3.6,8.4$ and 3.8 for protein, fat and carbohydrate, respectively, the last having been determined by difference and including fibre.

$4^{*}$ Factors $4.35,9.4$ and 4.2 for protein, fat and available carbohydrate, respectively.

carbohydrate, i.e. starch + sugar (as starch), 55.0 and 63.5; fibre 2.36 and 2.02 ; minerals $\mathrm{I} \cdot 53$ and $\mathrm{I} \cdot 53$ (assumed, see $\mathrm{McC}$ ance et al. 1945); carbohydrate, by difference, 63.50 and $71^{\circ} \cdot 10$ (this figure does not include fibre). 'Gross' calories are given in columns 2 and 3 of Table 9. Similar data have been fully discussed elsewhere by McCance et al. (1945). The available calories corrected for 'digestibility' by the combustion of the faeces in a calorimeter are given in column 4 and, after a further correction for incomplete combustion after absorption, in column 5. Column 6 shows the available calories determined by applying Atwater's general factors 4,9 and 4 to the protein, fat and carbohydrate (estimated by difference). These figures are too high, but they would have been lower if the 'carbohydrate' by difference had not included fibre (Committee on Calorie Conversion Factors, 1947). Column 7 gives the available calories determined by using factors based upon the figures for the digestibility of protein and fat obtained in this investigation and assuming one of $100 \%$ for starch and sugar. This assumption appears to be justified on the following grounds. Starch, as such, is never found in healthy faeces, and any amylase residues remaining in the digestive tract will contain $\mathrm{N}$, and will, therefore, detract from the apparent digestibility of the protein. These figures may be a little too low, since some energy may have 
been derived from pentosans and similar compounds in the bran, but on the whole they are excellent approximations, and for the English wheat the agreement with the bomb data is almost exact. The next column gives the available calories obtained by applying the factors recommended by Atwater for wheat to the protein, fat and carbohydrate, estimated by difference. These are fair approximations but they would have been better if the figure for carbohydrate had not, as recommended by the Committee on Calorie Conversion Factors (1947), included fibre. The last column gives the 'physiological' calories of the protein, fat, starch and sugar in the wheat, i.e. with no allowance made for digestibility. These are the figures which McCance \& Widdowson ( $1946 a$ ) consider should be used for the sake of consistency in food tables (see McCance et al. I945). If, therefore, it is desirable to assess the available calories in wheat by multiplying the protein, fat and carbohydrate by factors, it is suggested that the best approximation will be obtained by applying the factors 3.65 and 3.21 to the proteins of Canadian and English wheat respectively, and by using the factors 5.5 for fat and 4.2 for available carbohydrate. A fair approximation may be obtained by applying the factors $3.6,8.4$ and 3.8 to the protein, fat and carbohydrate, the last to be estimated 'by difference' but not to include fibre. It is possible that the former will give a figure which is a little too low and probable that the latter will give one which is rather too high.

\section{SUMMARY}

1. Metabolism experiments were made in which six subjects received wholemeal wheaten flour made from a high-protein Canadian wheat and from a low-protein English wheat. The wheats provided $85 \cdot 8-100 \%$ of the calories.

2. The digestibility of the calories in the Canadian flour was $88 \%$ and of those in the English flour $89 \%$. The former contained slightly more fibre.

3. The results indicate that the proteins of whole-wheat bread were completely or almost completely digested and absorbed, and that the $\mathrm{N}$ found in the faeces was entirely metabolic $N$. The 'apparent digestibility' of the proteins varied from $74 \cdot 2$ to 84.9 according to the amount of protein in the wheat.

4. The Canadian wheat contained more purines than the English wheat; $55-60 \%$ of them appeared to be absorbed and to be excreted in the urine as uric acid.

5. The digestibility of whole-wheat fat was found to be much lower than is generally supposed. It averaged $62.2 \%$ for Canadian and $53.9 \%$ for English wheat.

6. All the subjects were in negative calcium balance during these experiments, and one of them had a severe attack of tetany at their close.

7. The procedures and factors for assessing the available and other calories in whole wheat have been discussed, and recommendations have been made as to the best ones to use.

The authors are very much indebted to Dr T. Moran and other members of the Cereals Research Station at St Albans, particularly Drs R. H. Carter and J. C. Hinton, for their kindness and help with methods and supplies; also to $\mathrm{Mr} \mathrm{C}$. J. L. Baker for the calorie determinations. 


\section{REFERENCES}

Association of Official Agricultural Chemists (1945). Official and Tentative Methods of Analysis, 6th ed. Washington: Association of Official Agricultural Chemists.

Basu, K. P. (1946). Spec. Rep. Indian Res. Fd Ass, no. 15.

Basu, K. P. \& Nath, H. P. (1946). Indian Y. med. Res. 34, 13.

Best, C. H. \& Taylor, N. B. (1945). The Physiological Basis of Medical Practice, 4th ed. Baltimore: Williams and Wilkins Co.

Booth, R. G. \& Moran, T. (1946). Lancet, 251, 119.

Borgström, S. (194r). Acta physiol. scand. 2, suppl. 7.

Brull, L., Barac, G., Brakier-Zelkowiecz, T., Clemens, P., Crismer, R., Deltombe, J., Divry, A., Dubois, L., Dumont, L., Dumont-Ruyters, L., Lambrechts, A., Neuprez, R., Nizet, A., Op de Beeck, M.-J., Piersotte, J. \& Thomas, A. (1945). Les Etats de Carence en Belgique pendant l'Occupation Allemande 1940-4, p. 18r. Liége: Éditions Solédi; Paris: Hermann et Cie.

Cole, S. W. (1933). Practical Physiological Chemistry, 9th ed. Cambridge: W. Heffer and Sons Ltd.

Committee on Calorie Conversion Factors and Food Composition Tables, Convened by the Nutrition Division of the Food and Agriculture Organization of the United Nations (1947). Energy-yielding Components of Food and Computation of Calorie Values. Washington: Food and Agriculture Organization of the United Nations.

Fellenberg, T. von (1918). Biochem. Z. 88, 323.

Graff, S. \& Maculla, A. (1935). F. biol. Chem. 110, 71 .

Great Britain Parliament (1932). The Fertilisers and Feeding Stuffs Regulations, Statutory Rules and Orders, 1932, no. 658 .

Henry, K. M. \& Kon, S. K. (1945). 3. Soc. chem. Ind., Lond., 64, 227.

Heupke, W. (1943). Dtsch. Z. Verdau.- u. StoffroKr. 7, 49.

Langworthy, C. F. \& Holmes, A. D. (1917a). Bull. U.S. Dep. Agric. no. 505.

Langworthy, C. F. \& Holmes, A. D. (1917b). Bull. U.S. Dep. Agric. no. 507.

Lieberman, L. von \& Szekely, S. (1898). Pflizg. Arch. ges. Physiol. 72, 360.

Macrae, T. F., Hutchinson, J. C. D., Irwin, J. C., Bacon, J. S. D. \& McDougall, E. I. (1942). F. Hyg., Camb., 42, 423.

McCance, R. A. \& Shipp, H. L. (1933). Spec. Rep. Ser. med. Res. Coun., Lond., no. 187.

McCance, R. A. \& Widdowson, E. M. (1942). F. Physiol. 1or, 44.

McCance, R. A. \& Widdowson, E. M. (1946a). Spec. Rep. Ser. med. Res. Coun., Lond., no. 235, and ed.

McCance, R. A. \& Widdowson, E. M. (1946b). Spec. Rep. Ser. med. Res. Coun., Lond., no. 254.

McCance, R. A. \& Widdowson, E. M. (1947). F. Hyg., Camb., 45, 59.

McCance, R. A., Widdowson, E. M., Moran, T., Pringle, W. J. S. \& Macrae, T. F. (1945). Biochem. J. 39, 213.

Mitchell, H. H. (1924). F. biol. Chem. 58, 873 .

Mitchell, H. H. \& Carman, G. G. (1926). F. biol. Chem. 68, 183.

Moran, T. \& Pace, J. (1942). Nature, Lond., 150, 224.

Murlin, J. R., Marshall, M. E. \& Kochakian, C. D. (194I). Y. Nutrit. 22, 573.

Sealock, R. R., Basinski, D. H. \& Murlin, J. R. (194I). F. Nutrit. 22, 589.

Sherman, H. C. (1937). The Chemistry of Food and Nutrition, 5th ed. New York: The Macmillan Co. 